Original Article

\title{
Recent progress in magnetic nanoparticles and mesoporous materials for enzyme immobilization: an update
}

\author{
Progresso recente em nanopartículas magnéticas e materiais mesoporosos para \\ imobilização de enzimas: uma atualização
}

S.-S. Dinga\#, J.-P. Zhu", Y. Wanga, Y. Yuª and Z. Zhao ${ }^{\mathrm{a} *}$ (1)

ajiangsu University of Science and Technology, School of Grain Science and Technology, Zhenjiang, P.R. China \#The authors contributed equally to the work.

\begin{abstract}
Enzymes immobilized onto substrates with excellent selectivity and activity show a high stability and can withstand extreme experimental conditions, and their performance has been shown to be retained after repeated uses. Applications of immobilized enzymes in various fields benefit from their unique characteristics. Common methods, including adsorption, encapsulation, covalent attachment and crosslinking, and other emerging approaches (e.g., MOFs) of enzyme immobilization have been developed mostly in recent years. In accordance with these immobilization methods, the present review elaborates the application of magnetic separable nanoparticles and functionalized SBA-15 and MCM-41 mesoporous materials used in the immobilization of enzymes.
\end{abstract}

Keywords: functioned MCM-41 and SBA-15 mesoporous material, magnetic nanoparticle, enzyme immobilization.

\begin{abstract}
Resumo
Enzimas imobilizadas em substratos com excelente seletividade e atividade apresentam alta estabilidade e podem suportar condições experimentais extremas, e seu desempenho foi mantido após repetidos usos. As aplicações de enzimas imobilizadas em vários campos se beneficiam de suas características únicas. Métodos comuns, incluindo adsorção, encapsulamento, ligação covalente e reticulação, e outras abordagens emergentes (por exemplo, MOFs) de imobilização de enzima, foram desenvolvidos principalmente nos últimos anos. De acordo com esses métodos de imobilização, a presente revisão elabora a aplicação de nanopartículas magnéticas separáveis e materiais mesoporosos funcionalizados SBA-15 e MCM-41 usados na imobilização de enzimas.
\end{abstract}

Palavras-chave: material mesoporoso funcionado MCM-41 e SBA-15, nanopartícula magnétiaca, imobilização enzimática.

\section{Introduction}

Due to their excellent ability to boost the rate of chemical and biochemical reactions, enzymes have been widely used as catalysts in various fields, including but not limited to the textile industry, pharmaceutical industry, steal industry, animal feed, daily cosmetics, food industry, environmental governance and bioenergy utilization (Gurung et al., 2013; Jegannathan and Nielsen, 2013; Choi et al., 2015; Dwevedi, 2016; Escamilla-Alvarado et al., 2017). Their extensive application in industrial production is demonstrated by a respectable averaged annual growth rate of $4.6 \%$ over the past decades (Datta et al., 2013). The demand for proteases and lipases claims more than $70 \%$ share of the global enzyme market, amounting to as much as 5 billion US dollars, and is predicted to increase to 17.5 billion US dollars by 2024 (Han et al., 2015; Mohamad et al., 2015; Mojsov, 2016; Patel et al., 2016; Guerrand, 2017). The inherent characteristics of instability, low reusability

and high cost are severe limitations and prevent enzymes from evolving into a cost-effective option (Minteer, 2017). The application of immobilization techniques could alleviate these disadvantages and therefore has emerged and developed gradually since the 1970s (Vaghari et al., 2016; Bernal et al., 2018). Enzyme immobilization offers the advantage of maintaining and developing robust biocatalyst activity under harsh operational conditions for a long time (Landarani-Isfahani et al., 2015; Rueda et al., 2016). Aside from carrier-free immobilization and carrier-bound immobilization as the main methods (Wang et al., 2015), adsorption (Klein et al., 2016; Nguyen and Kim, 2017), covalent attachment (Wu et al., 2015), crosslinking and encapsulation are also frequently used in enzyme immobilization (Bezerra et al., 2015; Majewski et al., 2017; Ma et al., 2018; Singh et al., 2019).

*e-mail: zongpeizhao@just.edu.cn

Received: October 11, 2020 - Accepted: November 20, 2020 
Aside from optimizing immobilization methods, the selection of suitable support materials is also vital in industrial production (Santos et al., 2015). These materials can input their specific properties upon immobilization, given that the properties of the supported enzyme are determined by both the enzyme and the support material (Bilal et al., 2018). For instance, magnetic nanoparticles (MNPs) are valued for their high surface area, large surface-area-to-volume ratio and easy separation under external magnetic fields (Liu et al., 2018; Shiri et al., 2018). Moreover, porous materials feature large pore diameters and outstanding carrying capacities (Sun et al., 2016; Abe et al., 2017, Cacicedo et al., 2019). Low cost, thermal resistance, high reusability and stability are the desired features of ideal support materials (Zdarta et al., 2018). Since the pore size of mesoporous materials can be mediated continuously from $2 \mathrm{~nm}$ to $50 \mathrm{~nm}$, they are suitable and ideal materials for enzyme fixation (Baino et al., 2016).

In recent years, magnetic materials, mesoporous materials, and metal-organic materials have led to many beneficial changes in enzyme immobilization studies, which have the potential to advance their industrial production. This review provides an update on the research on enzyme immobilization by MNPs and the functionalized mesoporous materials SBA-15 and MCM-41 in the last five years and discusses the changes in enzyme properties and the application of immobilization support materials.

\section{Magnetic nanoparticles}

Bypassing the procedures of catalyst filtration or centrifugation after a finished reaction, magnetic separation is a practical approach to recycle magnetized catalysts (Shokouhimehr, 2015; Zhang et al., 2016). Magnetic materials are extensively used in the separation process after enzyme catalytic reactions because of their excellent adsorption to magnetic substances, which enhances their reusability and reduces the cost of immobilized enzymes (Vaghari et al., 2016; Zhao et al., 2019).
We reviewed the application of enzyme immobilization by using MNPs over the past five years and found that organic polymer-functionalized and mesoporous material-functionalized MNPs are frequently used for enzyme immobilization (Table 1) (Bilal et al., 2018). Herein, we elaborate on applications that can improve the stability of enzymes and enhance their catalytic efficiency. Silica-coated nanocomposites provide a core-shell structure to preserve the properties of the enzyme, whereas organic materials prevent the accumulation of immobilized enzyme, and in mesoporous materials, organosilane is introduced into the mesoporous matrix to increase the loading capacity and to prevent leaching.

\subsection{Mesoporous material-functionalized MNPs}

The formation of functionalized silica coatings improves the chemical stability and biocompatibility of magnetic nanoparticle surfaces, providing outstanding supports by preventing nanoparticle aggregation in solution (Mahto et al., 2016; Gao et al., 2017a). In the application of immobilized enzymes, surface-modified nanomaterials promote particle dispersion and enhance antioxidant capacity, thus modulating the reaction features. In metal nanoparticles and metal magnetic nanoparticles, $\mathrm{Fe}_{3} \mathrm{O}_{4}$ is the most common material. In the methods of modification, organic molecule modification uses surfactant, a silylation coupling agent (3-aminopropyltriethoxysilane APTES), and an organic polymer, whereas inorganic modification applies silica core-shell particles (Mahto et al., 2016; Gkaniatsou et al., 2018) and mesoporous silica (Gao et al., 2017a). The immobilization of mesoporous material-coated MNPs is shown in Figure 1.

Here, silica coating is a unique method because it helps form a silica shell on the surface of the magnetic core for the functionalization/modification of $\mathrm{Fe}_{3} \mathrm{O}_{4}$ nanoparticles (Cui et al., 2017, 2018a, b). The formation of the silica shell can protect the magnetic core from aggregation and oxidation, thereby improving its chemical stability. Additionally, it also enhances the characteristics of

Table 1. Enzyme immobilization on MNPs.

\begin{tabular}{|c|c|c|c|c|}
\hline $\begin{array}{l}\text { Immobilization } \\
\text { Method }\end{array}$ & Support material & Enzyme & $\begin{array}{l}\text { Improved Enzyme } \\
\text { Properties }\end{array}$ & Ref \\
\hline Covalent Bond & $\mathrm{Fe}_{3} \mathrm{O}_{4}$ nanoparticles & $\begin{array}{l}\text { Candida antarctica } \\
\text { lipase B }\end{array}$ & Stability & $\begin{array}{l}\text { (Gkaniatsou et al., } \\
\text { 2018) }\end{array}$ \\
\hline Covalent Bond & $\mathrm{Fe}_{3} \mathrm{O}_{4}$ nanocomposites & Lipase & $\begin{array}{l}\text { Hydrophilicity and } \\
\text { biocompatibility }\end{array}$ & $\begin{array}{l}\text { (Mahto et al., } \\
\text { 2016) }\end{array}$ \\
\hline Crossing-linking & $\begin{array}{l}\text { Tannic-acid-templated magnetic } \\
\text { mesoporous silica nanoparticles } \\
\text { (TA-MMSNs) }\end{array}$ & NHase & Yield & (Gao et al., 2017a) \\
\hline Crossing-linking & $\begin{array}{l}\text { Polydopamine (PDA)-functionalized } \\
\text { magnetic nanoparticle }\end{array}$ & DNA catalytic & $\begin{array}{l}\text { Stability and } \\
\text { reusability }\end{array}$ & (Yang et al., 2018) \\
\hline Crossing-linking & $\begin{array}{l}\text { PAL-coated magnetic } \\
\text { nanoparticles }\end{array}$ & $\begin{array}{l}\text { Phenylalanine } \\
\text { ammonia-lyase } \\
\text { (PAL) }\end{array}$ & Reproducibility & $\begin{array}{l}\text { (Ender et al., } \\
\text { 2016) }\end{array}$ \\
\hline Crossing-linking & $\begin{array}{l}\text { Dendritic polymer-modified } \\
\text { nanoparticles }\end{array}$ & Lipase & Yield & (Li et al., 2018) \\
\hline
\end{tabular}


hydrophilicity and biocompatibility of the material. During silica coating, Candida antarctica lipase B was adsorbed to MNPs modified by 1-(3-dimethylaminopropyl)-3ethylcarbodiimide and 1-hydroxy-2,5-pyrrolidinedione. After 10 min of reaction, $\mathrm{HPD} / \mathrm{ECD}$ aqueous solutions had a strong activating effect on the carboxylic acid group of Candida antarctica lipase B at RT. Additionally, the amino groups were attached to the surface of $\mathrm{Fe}_{3} \mathrm{O}_{4}$ nanoparticles by covalent bonds. Thus, superparamagnetic materials and functionalized nanoparticles that remained dispersive were employed to immobilize the lipase under mild conditions. The enzyme maintained its stability throughout the process (Gkaniatsou et al., 2018).

Additionally, silicon dioxide shells protect nuclei from aggregation and oxidation, improving their chemical stability by increasing biocompatibility and hydrophilicity (Poorakbar et al., 2018). The changed optimum pH values after immobilization were mostly caused by the immobilization of magnetically mesoporous silica nanocomposites with polyaniline functionalized (Pani-MS@ $\mathrm{Fe}_{3} \mathrm{O}_{4}$ ) by multipoint immobilization to ensure the stability of lipase molecules. Recent studies demonstrated that mesoporous silica-immobilized lipase modified with polyaniline showed high activity across a wide $\mathrm{pH}$ range and high temperature stability, which was attributed to the change in the optimal pH in Pani-MS@ $@ \mathrm{Fe}_{3} \mathrm{O}_{4}$ by multipoint fixation facilitating the stabilization of lipase molecules by $\mathrm{Fe}_{3} \mathrm{O}_{4}$ nanocomposites (Mahto et al., 2016). Notably, the advantages of immobilized NHase included improvements in the loading capacity, ease of separation and recycling of materials (Gao et al., 2017b). Moreover, tannic acid-modified magnetic mesoporous silica was crosslinked with the enzyme glutaraldehyde to form crosslinked nitrile hydratase aggregates, which were characterized by a high loading rate, easy separation and recovery of materials compared to those of the free enzyme (Gao et al., 2017a). Moreover, the activities of free NHase and tannic acid-templated magnetic mesoporous silica nanoparticle-immobilized NHase (CLNHAs@TA-MSNs) were highest at $30^{\circ} \mathrm{C}$ and $40^{\circ} \mathrm{C}$, respectively. CLNHAs@ TA-MSNs had a higher optimum temperature than free NHase. The reason is that the active conformation of NHase molecules could be maintained at high temperatures through multipoint covalent bonds between NHase molecules and TA-MSNs, whereas the destruction of the conformation of CLNHAs@TA-MSNs required much more energy.

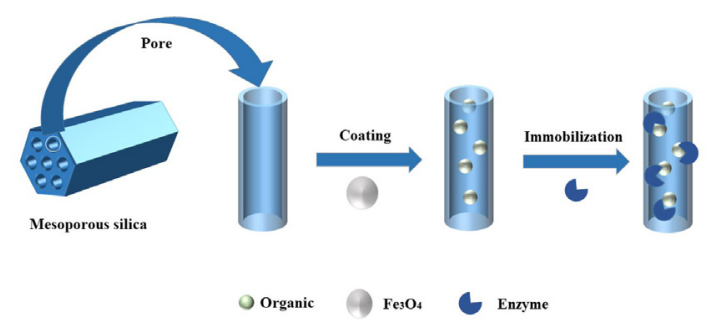

Figure 1. Mesoporous material-functioned MNPs.
The large specific surface area, adjustable pore size and easy surface functionalization make mesoporous silica materials ideal carriers in catalytic reactions. Moreover, MNPs have potential application value in the field of magnetic separation due to their low toxic side effects and special magnetic properties. However, simple magnetic nanoparticles are prone to agglomeration. In future research, additional attention should be paid to the immobilization of MNPs in combination with mesoporous silica materials.

\subsection{Organic polymer-functionalized MNPS}

Compared with mesoporous silica-immobilized enzymes, organic polymer magnetic material-immobilized enzymes are widely used as lightweight materials due to their low density, structural diversity and easy processing (Figure 2). Generally, in situ modification and ectopic modification are the two methods used for modifying MNPs with organic polymers. During in situ modification, the organic polymer is added as a stabilizer to the precursor solution to form $\mathrm{Fe}_{3} \mathrm{O}_{4}$ nanoparticles, and the polymer coating is synthesized on the polymerized monomer. However, the repulsive force generated by the polymer coating tends to weaken the magnetic properties. Thus, the enzymes interact with the material via van der Waals interactions to prevent their aggregation and improve the stability and dispersion.

One study described the preparation of a mild and versatile immobilized enzyme reactor by applying DNA-directed immobilization (DDI) to anchor trypsin on polydopamine (PDA)-functionalized magnetic nanoparticles (MNPs). The reactor exhibited outstanding reusability and improved catalytic efficiency. Notably, the immobilized trypsin reactor maintained $55 \%$ of its initial activity even after 70 cycles of reaction at pH 9.0 and $37^{\circ} \mathrm{C}$. Its outstanding properties are mostly ascribed to immobilization by DDI, which is attached to the vector by a DNA splice that acts as a linkage between the enzyme and the vector. DNA, as a spacer molecule, allows the free use of the enzyme functional units to enhance the conformation of the enzyme. The functional units of the enzyme (e.g., active sites) are freely available to enhance its conformation, thereby boosting its activity and potency (Yang et al., 2018). Ferenc Ender et al. (2016), introduced a novel microfluidic device (Magne-Chip) containing microliter-volume reaction cells filled with PAL-coated magnetic nanoparticles (MNPs), which could be used as a novel efficient and flexible tool for the enzyme-catalyzed

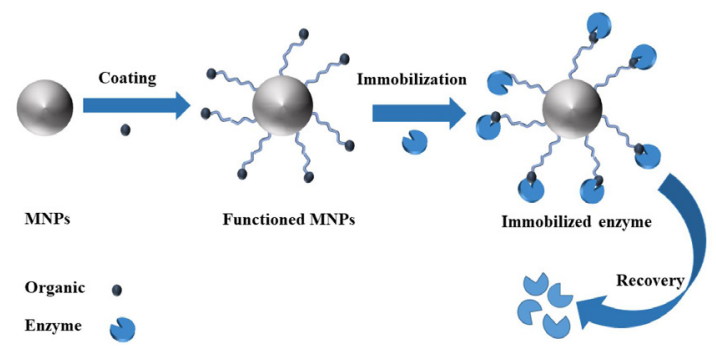

Figure 2. Organic polymer-functioned MNPs. 
biotransformation of L-phenylalanine (L-1a) and five unnatural substrates (rac-1b-f) by phenylalanine ammonia-lyase (PAL). The experimental results showed the excellent reproducibility of enzyme-catalyzed biotransformation in the chip and the high reusability of the enzyme layer during 14 hours of continuous measurement ( $>98 \%$ over 7 repetitive measurements with L-1a) (Ender et al., 2016). In this work, a novel melamine-glutaraldehyde dendrimer was first grafted onto amino-magnetic nanoparticles to facilitate the immobilization of lipase on the protein-binding site. Dendritic polymer-modified nanoparticles were used to control the lipase conformation to enhance the potential of contact with the lipase catalytic center. The activity of immobilized lipase was approximately 58.0 times higher than that of BCL powder and 3.0 times higher than that of immobilized lipase from unmodified polymer. Moreover, the time required for the reaction was reduced from 180 mins to 20 mins. However, due to the weak physical adsorption interaction between the enzyme and the carrier, enzyme leakage may occur in each batch of the reaction, resulting in increased costs for separation and purification of downstream products (Li et al., 2018).

Overall, the application of magnetic nanomaterial MNPs for enzyme immobilization has shown satisfactory performance. The protective effect of the MNP material on the enzyme increases the stability of the enzyme under acidic and thermal conditions, and the MNPs, as magnetic materials, provide better recycling performance. In addition, enzymes linked to these polymers by noncovalent or covalent bonds to produce biocatalysts can be used as homogeneous catalysts, and applying appropriate stimuli can result in high reusability of the immobilized enzyme (Singh et al., 2013; Shahrestani et al., 2016; Fletcher et al., 2019; Suo et al., 2020).

\section{Mesoporous materials}

\subsection{Functional group-modified SBA-15}

SBA-15 mesoporous materials with tunable pore diameters (from 20 to $50 \mathrm{~nm}$ ) can be synthesized for various applications (Meléndez-Ortiz et al., 2016). A chemical covalent bond is formed between the functional groups on the enzyme protein molecule and the reactive group on the mesoporous material, forming an immobilized product with a strong binding force to ensure the stability of the enzyme during the catalytic reaction (Gholamzadeh et al., 2017; Yang et al., 2019). After the introduction of different organosilanes (amino, cyano, epoxy or mercapto) onto the surface or the pores of the mesoporous matrix, the presence of these functional groups generates many reaction sites for subsequent attachment of enzymes, thereby improving the loading capacity and preventing the leaching of the enzyme (Zhong et al., 2019). The procedure of enzyme immobilization on mesoporous materials via covalent bonds is illustrated in Figure 3.

SBA-15 materials have a high specific surface area, ordered structure and large pore volume, which provide high immobilization efficiency (Bhanja et al., 2017;

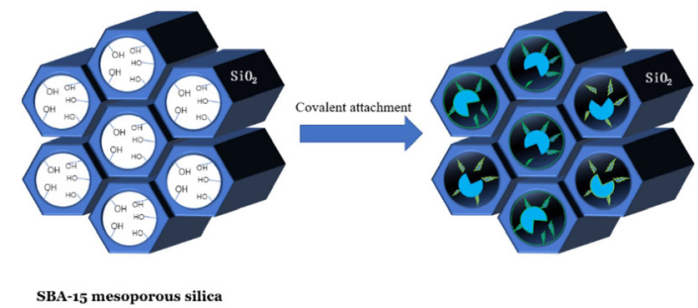

Figure 3. Enzyme immobilization on mesoporous materials.

Wongvitvitchot et al., 2019). Moreover, SBA-15 can provide $\mathrm{pH}$ protection, which is influenced by the pore size of the material (Lynch et al., 2016). In addition, SBA-15 can be optimized by postmodication, and when functionalized or modified SBA-15 is used for immobilizing enzymes, their thermal stability and $\mathrm{pH}$ sensitivity are further improved (Rios et al., 2016; Zhong et al., 2019). Immobilization of enzymes by SBA-15 after the introduction of a suitable bridging agent can also improve the enzyme stability and reusability as well as the $\mathrm{pH}$ and temperature tolerance (Xiang et al., 2018). In studies of enzyme immobilization with mesoporous materials as carriers, lipase accounts for a large fraction (Gholamzadeh et al., 2017). Based on production requirements, lipase immobilized with the mesoporous material SBA-15 is used to catalyze chemical reactions, including esterification and transesterification (Zhao et al., 2015; Gholamzadeh et al., 2017). Here, we summarized the recent progress on lipases immobilized with various support materials (Table 2 ).

\subsubsection{Functionalized SBA-15 for lipase immobilization}

Over the last 20 years, SBA-15 has been widely used for immobilizing lipase. In recent years, organically modified and ionic liquid-modified SBA-15 have shown satisfactory performance in enzyme immobilization (Abolghasemi et al., 2016; Kong et al., 2016; Yuan et al., 2016). The immobilization of Candida antarctica lipase $B$ (CALB) by using mesoporous SBA-15 resulted in improved enzymatic activity and stability. The thermal stability of CALB after immobilization greatly depends on its moisture content; when it reached 3.22\%, and its thermal stability was significantly improved (Cai et al., 2016). Moreover, higher protein rigidity contributed to 4-12 times higher thermal stability of immobilized lipase at $60^{\circ} \mathrm{C}$ than that of free lipase (Živković et al., 2015).

As imidazole-based ionic liquids (ILs) boost enzyme bioactivity, the immobilization of CALB on a carrier (IL-SBA-15) could be achieved by modifying the mesoporous silica SBA-15. The hydrophilic carrier promoted the enzyme activity because it retained the essential aqueous layer of lipase and hence prevented the impairment of the catalytic activity (Zhong et al., 2018). Moreover, recombinant Candida antarctica lipase B (LIPB) expressed in Pichia pastoris was immobilized in SBA-15 to produce the biocatalyst SBA-15-LIPB-GA via glutaraldehyde (GA) crosslinking. The biocatalyst showed excellent thermal and solvent stability. Hydrophobic interactions were probably the main driving force of the adsorption (Rios et al., 2018). Notably, 
Table 2. Enzyme immobilization on SBA-15 mesoporous materials.

\begin{tabular}{|c|c|c|c|c|}
\hline $\begin{array}{l}\text { Immobilization } \\
\text { Method }\end{array}$ & Support material & Enzyme & $\begin{array}{l}\text { Improved Enzyme } \\
\text { Properties }\end{array}$ & Ref \\
\hline Cross-Linking & $\begin{array}{l}\text { Epoxy functionalized } \\
\text { SBA-15 }\end{array}$ & Carbonic anhydrase & Storage stability & (Fei et al., 2016) \\
\hline Cross-Linking & $\begin{array}{l}\text { Aminoy Functionalized } \\
\text { SBA-15 }\end{array}$ & Carbonic anhydrase & Storage stability & (Fei et al., 2016) \\
\hline Encapsulation & $\begin{array}{l}\text { Mesoporous Silica SBA- } \\
15\end{array}$ & Alkaline protease & Enzyme Activity & (Kumari et al., 2015) \\
\hline Cross-linking & $\begin{array}{l}\text { Mesoporous Silica SBA- } \\
15\end{array}$ & Lysozyme & PH Resistance & (Lynch et al., 2016) \\
\hline Covalent bond & $\begin{array}{l}\text { Aminofunctionalized } \\
\text { SBA-15 }\end{array}$ & Laccase & Biodegradation & (Bautista et al., 2015) \\
\hline Adsorption & $\begin{array}{l}\text { Mesoporous Silica SBA- } \\
15\end{array}$ & Candida rugosa lipase & $\begin{array}{l}\text { Affinity and } \\
\text { thermostability }\end{array}$ & (Živković et al., 2015) \\
\hline Adsorption & $\begin{array}{l}\text { Mesoporous Silica SBA- } \\
15\end{array}$ & $\begin{array}{l}\text { Candida antarctica } \\
\text { Lipase B }\end{array}$ & $\begin{array}{l}\text { Enzyme activity and } \\
\text { stability }\end{array}$ & (Cai et al., 2016) \\
\hline Covalent bond & $\begin{array}{l}\text { Amino acid modified } \mathrm{S} \\
\text { BA-15 }\end{array}$ & $\begin{array}{l}\text { Porcine pancreases } \\
\text { lipase }\end{array}$ & Heat resistance & (Zou et al., 2013) \\
\hline Adsorption & Magnetic $\mathrm{Fe}_{3} \mathrm{O}_{4} / \mathrm{SBA}-15$ & Candida rugosa lipase & Easily separated & (Rios et al., 2016) \\
\hline Adsorption & $\begin{array}{l}\text { Mesoporous Silica SBA- } \\
15\end{array}$ & $\begin{array}{l}\text { Candida antarctica } \\
\text { lipase B }\end{array}$ & Thermal stability & (Rios et al., 2016) \\
\hline Cross-linking & SBA-15-LIPB-GA & $\begin{array}{l}\text { Candida antarctica } \\
\text { lipase B }\end{array}$ & $\begin{array}{l}\text { High activity and } \\
\text { stability }\end{array}$ & (Rios et al., 2018) \\
\hline Cross-linking & $\mathrm{NH}_{2}-\mathrm{SBA}-15$ & Acetylcholinesterase & $\begin{array}{l}\text { Immobilization } \\
\text { efficiency }\end{array}$ & (Rui et al., 2018) \\
\hline Covalent bond & $\begin{array}{l}\text { Mesoporous SBA-15 } \\
\text { silica }\end{array}$ & Polyphenol oxidase & Enzyme efficiency & (Escuin et al., 2017) \\
\hline Covalent bond & $\begin{array}{l}\text { Ionic Liquids Modified } \\
\text { SBA-15 }\end{array}$ & $\begin{array}{l}\text { Candida antarctica } \\
\text { Lipase B }\end{array}$ & Enzymatic activity & (Zhong et al., 2018) \\
\hline
\end{tabular}

Rios NS et al., have shown that the surface of SBA-15 can be treated with 3-amino-propyltriethoxysilane (APTES) to form SBA-15-APTES. After activation, incubation (at pH 10.2) and divinyl sulfone (DVS) treatment, the biocatalyst SBA-15-APTES-DVS-LIPB can be obtained, which combines multipoint covalent bonds between the enzyme and its carrier at $50^{\circ} \mathrm{C}$ and $\mathrm{pH} 7.0$; SBA-15-LIPB-GA was reused for five cycles, and retained $76.80 \%$ of its initial activity after the third cycle (Rios et al., 2016).

All these above studies indicated that lipase immobilized using the mesoporous material SBA- 15 showed improved thermal stability and enzymatic bioactivity. In addition, the immobilization of lipase into the modified mesoporous material SBA-15 exhibited superior properties compared to unmodified mesoporous material in terms of improved thermal stability, activity and solvent stability of the immobilized lipase.

\subsubsection{Functionalized SBA-15 for immobilization of other enzymes}

In addition to their ability to be applied to the immobilization of lipases, SBA-15 mesoporous materials used in immobilizing other enzymes have also been reported. The conversion rates of aminobutyl-based laccase to naphthalene, phenanthrene and anthracene were $82 \%$, $73 \%$ and $55 \%$, respectively, which is close to the conversion rate of free enzymes. However, laccase technology based on aminopropyl-modified SBA-15 led to satisfactory covalent immobilization. In addition, the aminopropyl-grafted laccase on SBA-15 exhibited the best reusability, and after 4 cycles, it had a higher activity than the aminobutyl-based laccase after 4 cycles (Bautista et al., 2015). Moreover, the method of acetylcholinesterase (AChE) immobilized on the amino-functionalized SBA-15 mesoporous sieve $\mathrm{NH}_{2}$-SBA-15 was reported and applied to the determination of organophosphorus and carbamate pesticides. With regard to different immobilization techniques, we found that the adsorption-crosslinking technique was the best method. Specifically, the results indicated that AChE- $\mathrm{NH}_{2}$-SBA-15 had a high immobilization efficiency of 95\% (Rui et al., 2018). Escuin PC et al., also compared and analyzed the immobilization of polyphenol oxidase (PPO) by various mesoporous SBA- 15 silica materials at different $\mathrm{pH}$ values. The results showed that the pore size and volume of the carrier were the main structural characteristics affecting PPO immobilization. When the $\mathrm{pH}$ value reached 4.0 , the carrier achieved a maximum load of PPO 
(Escuin et al., 2017). Two functionalized SBA-15 materials with different types of functional groups, aminefunctionalized SBA-15 (AFS) and epoxy-functionalized SBA-15 (GFS), were prepared by treatment with APTES and 3-glycidyloxypropyltrimethoxysilane (GTMS), respectively, for post functionalization. Specifically, carbonic anhydrase (CA) reached its maximum activity at pH 10.0 (Fei et al., 2016). Kumari et al., proposed a new procedure to prepare immobilized alkaline proteases on the surface of silanol-functionalized SBA-15, providing a promising platform for application as milk coagulants in cheese-making and further research. In this process, the method was applied to immobilize alkaline protease on SBA-15. SBA-15 has a surface silanol group, to which protease can be attached, resulting in a high stability. The enzyme stability was enhanced, and protease immobilization on SBA-15 exhibited a residual activity as high as 70\% after 12 reapplications (Kumari et al., 2015).

In conclusion, in some cases, the enzymes immobilized with SBA-15 had high recoveries, such as aminopropyl grafted-laccase on the SBA-15 material mentioned before. Covalent immobilization of SBA-15 with enzymes using amino-modified SBA-15 via glutaraldehyde crosslinking can improve the immobilization efficiency of immobilized enzymes and reusability, and the use of divinyl sulfone(DVS) crosslinked with amine-modified SBA- 15 for immobilizing enzymes can further enhance the thermal stability of immobilized enzymes. Epoxy-functionalized SBA-15 (GFS) has a more suitable pore size than amine-functionalized SBA-15 (AFS). Modifications in the pore volume, specific surface area and immobilized enzyme could all improve the CA stability at high $\mathrm{pH}$ values during immobilization (Fei et al., 2016).

\subsection{Modified MCM-41 materials}

Kresge et al., reported an ordered mesoporous material named MCM-41, a novel nanostructured material featuring ordered hexagonal arrangement and continuous adjustment of pore diameter ranged from 2 to $10 \mathrm{~nm}$, a size smaller than that of SBA-15 mesoporous materials (Xu et al., 2019). Currently, efforts have been made to analyze the utility of MCM-41 as a catalyst carrier (Jiang et al., 2016; Molaei et al., 2018; Polikarpova et al., 2018; Brezoiu et al., 2019). The pure silicon MCM-41 mesoporous material has low surface activity and poor stability, and is only used as a general carrier or adsorption material. In order to improve its performance, so that it can be used in a wider range of areas, it is necessary to modify it. At present, there are mainly the introduction of metal heteroatoms, organic modification or functionalization and load-type modification methods (Sang et al., 2013; Wu et al., 2016; Fellenz et al., 2017; Costa et al., 2020). The loading modification is a common method in immobilized enzymes by loading the active components ( such as $\mathrm{Fe}_{3} \mathrm{O}_{4}$ ) in the pore channel to improve the performance of the immobilized enzyme. The methods and materials for the above enzyme immobilization are listed in Table 3.

Recent reports have shown that the application of aqueous-organic two-phase systems to MCM-41 mesoporous materials enhances enzyme activity, among these cases, Chen et al., reported that Candida rugosa lipase immobilized on MCM-41 mesoporous molecules showed excellent performance during the resolution of racemic naproxen methyl ester. Immobilized lipase was found to have increased activity relative to free lipase. In the range of $\mathrm{pH}$ 6.5-8.5, higher $\mathrm{pH}$ increases activity but decreases selectivity of lipase enantioselectivity in the reaction (Chen et al., 2015).

Appaturi and Selvaraj immobilized catalyst on the surface of DL-Alanine functionalized MCM-41. The durability of catalyst and rate of production (3-(2-furylmethylene)-2, 4-pentanedione) were significantly enhanced than that of the free one. Studies have shown that the alanine molecule has been successfully immobilized on MCM-41. 16Alanine-MCM-41 can be effective for the condensation reaction of furfural with acetylacetone under solvent-free conditions. The catalyst exhibited excellent performance, i.e., $92.41 \%$ of the main product 3-(2-furylmethylene)-2, 4-pentanedione, due to its high selectivity for substrates (Appaturi et al., 2018). Of most recent, Xie et al., reported a structured $\mathrm{Fe}_{3} \mathrm{O}_{4}$-MCM-41 nanoparticles, which provided a protective layer on the surface of immobilized lipase. The compound involved covalent linking using glutaraldehyde as the cross-linking reagent onto the surface of materials, demonstrating excellent enzyme kinetic properties. The catalytic properties for the bound lipase carried out in the esterification of lard and soybean oil, showing that higher catalytic activity of immobilized lipases for the interesterification reaction, lower melting point of the final product than the original mixture (Xie and Zang, 2016). Besides, MCM-41 nanoparticles were

Table 3. Enzyme immobilization on MCM-41 mesoporous materials.

\begin{tabular}{lllll}
\hline $\begin{array}{c}\text { Immobilization } \\
\text { Method }\end{array}$ & \multicolumn{1}{c}{ Support material } & \multicolumn{1}{c}{ Enzyme } & \multicolumn{1}{c}{$\begin{array}{c}\text { Improved Enzyme } \\
\text { Properties }\end{array}$} & Ref \\
\hline Covalent Bond & $\begin{array}{l}\text { Alanine Functionalized } \\
\mathrm{MCM}-41\end{array}$ & $\begin{array}{l}\text { DL-Alanine } \\
\text { functionalized } \\
\text { MCM-41 catalyst }\end{array}$ & $\begin{array}{l}\text { Substrate } \\
\text { Selectivity }\end{array}$ & $\begin{array}{l}\text { (Gkaniatsou et al., } \\
\text { 2018) }\end{array}$ \\
Encapsulation & $\mathrm{CPS} / \mathrm{GO}-\mathrm{Fe}_{3} \mathrm{O}_{4} @ \mathrm{MCM}-41$ & Porcine pancreas lipase & Reusability & $\begin{array}{l}\text { (Mahto et al., } \\
\text { 2016) }\end{array}$ \\
Covalent Bond & $\begin{array}{l}\text { MCM-41 coated with } \\
\text { polyethylenimine }\end{array}$ & $\begin{array}{l}\text { Rmomyces lanuginosa } \\
\text { lipase }\end{array}$ & $\begin{array}{l}\text { Stability and } \\
\text { reusability }\end{array}$ & (Gao et al., 2017a) \\
Encapsulation & $\mathrm{Fe}_{3} \mathrm{O}_{4}-\mathrm{MCM}-41$ & Candida rugosa lipase & Enzyme Activity & (Yang et al., 2018) \\
\hline
\end{tabular}


coated with polyethyleneimine (MCM-41@PEI) and chelated by further modification of divalent metal ions $\left(\mathrm{M}=\mathrm{Co}^{2+}, \mathrm{Cu}^{2+}\right.$ or $\left.\mathrm{Pd}^{2+}\right)$ to produce metal-chelated silica nanoparticles particles (MCM-41@PEI-M). Thermomyces lanuginosa lipase (TLL) was immobilized by physical adsorption on MCM-41@PEI. The results showed that the highest biocatalytic activity at very acidic and basic $\mathrm{pH}$ ( $\mathrm{pH}=3.0$ and 10.0) values were achieved by MCM-41@ PEI-Co and MCM-41@PEI-Cu. While for different catalytic temperatures, MCM-41@PEI-Co maintained the highest activity at $75^{\circ} \mathrm{C}$ (Sadighi et al., 2017)

\section{Conclusions}

We summarized recent studies on the role of MNPs and the functionalized mesoporous materials SBA-15 and MCM-41 in immobilized enzyme applications. The traditional process of adsorption--immobilized enzymes is relatively simple, and the conformation of the enzyme is rarely affected, but the immobilization effect is not obvious. The reusability of immobilized enzymes can be improved due to the high adsorption of magnetic nanomaterial MNPs to magnetic substances. When mesoporous material-modified MNPs are applied to immobilized enzymes, due to the increased protection of the enzyme by the silica gel shell, the immobilized enzyme shows stability under harsh conditions. In addition, MNPs functionalized with organic polymers in immobilized enzymes can change multipoint covalent bonds, thus further promoting the catalytic efficiency. Furthermore, the specific structure of SBA-15 and MCM-41 enhances the binding capacity between the enzyme and substrate due to the increased spatial resistance and thus contributes to the excellent loading capacity of the immobilized enzyme.

Although several efforts have been made in the past few years to obtain versatile immobilization insights, joint studies are still necessary to evaluate the relationship of modified functional groups and carrier materials, binding sites between nanomaterials and enzymes and conformational shifts in the reactions. From previous successful studies, it can be concluded that the application of modified carrier material provides a vital approach for enzyme immobilization and several other fields.

\section{Acknowledgements}

This research received internal funding from Jiangsu University of Science and Technology (No.1182931903).

\section{References}

ABE, S., TABE, H., IJIRI, H., YAMASHITA, K., HIRATA, K., ATSUMI, K., SHIMOI, T., AKAI, M., MORI, H., KITAGAWA, S. and UENO, T., 2017. Crystal engineering of self-assembled porous protein materials in living cells. ACS Nano, vol. 11, no. 3, pp. 2410-2419. http://dx.doi.org/10.1021/acsnano.6b06099. PMid:28094987.

ABOLGHASEMI, M.M., HASSANI, S. and BAMOROWAT, M., 2016. Efficient solid-phase microextraction of triazole pesticides from natural water samples using a Nafion-loaded trimethylsilane- modified mesoporous silica coating of type SBA-15. Mikrochimica Acta, vol. 183, no. 2, pp. 889-895. http://dx.doi.org/10.1007/ s00604-015-1724-0.

APPATURI, J.N., SELVARAJ, M., and HAMID, S.B.A., 2018. Synthesis of 3-(2-furylmethylene)-2, 4-pentanedione using DL-Alanine functionalized MCM-41 catalyst via Knoevenagel condensation reaction. Microporous and Mesoporous Materials, 260, 260-269. https://doi.org/10.1016/j.micromeso.2017.03.031.

BAINO, F., FIORILLI, S. and VITALE-BROVARONE, C., 2016. Bioactive glass-based materials with hierarchical porosity for medical applications: review of recent advances. Acta Biomaterialia, vol. 42, pp. 18-32. http://dx.doi.org/10.1016/j.actbio.2016.06.033. PMid:27370907.

BAUTISTA, L. F., MORALES, G. and SANZ, R., 2015. Biodegradation of polycyclic aromatic hydrocarbons (PAHs) by laccase from Trametes versicolor covalently immobilized on aminofunctionalized SBA-15. Chemosphere, 136, 273-280. https:// doi.org/10.1016/j.chemosphere.2015.05.071.

BERNAL, C., RODRIGUEZ, K. and MARTINEZ, R., 2018. Integrating enzyme immobilization and protein engineering: an alternative path for the development of novel and improved industrial biocatalysts. Biotechnology Advances, vol. 36, no. 5, pp. 14701480. http://dx.doi.org/10.1016/j.biotechadv.2018.06.002. PMid:29894813.

BEZERRA, C.S., DE FARIAS LEMOS, C.M.G., DE SOUSA, M. and GONÇALVES, L.R.B., 2015. Enzyme immobilization onto renewable polymeric matrixes: past, present, and future trends. Journal of Applied Polymer Science, vol. 132, no. 26, pp. n/a. http://dx.doi.org/10.1002/app.42125.

BHANJA, P., MODAK, A., CHATTERJEE, S. and BHAUMIK, A., 2017. Bifunctionalized mesoporous SBA-15: a new heterogeneous catalyst for the facile synthesis of 5-hydroxymethylfurfural. ACS Sustainable Chemistry \& Engineering, vol. 5, no. 3, pp. 2763-2773. http://dx.doi.org/10.1021/acssuschemeng.6b03100.

BILAL, M., ZHAO, Y., RASHEED, T. and IQBAL, H.M., 2018. Magnetic nanoparticles as versatile carriers for enzymes immobilization: a review. International Journal of Biological Macromolecules, vol. 120, no. Pt B, pp. 2530-2544. http://dx.doi.org/10.1016/j. ijbiomac.2018.09.025. PMid:30201561.

BREZOIU, A.-M., DEACONU, M., NICU, I., VASILE, E., MITRAN, R.-A., MATEI, C. and BERGER, D., 2019. Heteroatom modified MCM-41silica carriers for Lomefloxacin delivery systems. Microporous and Mesoporous Materials, vol. 275, pp. 214-222. http://dx.doi. org/10.1016/j.micromeso.2018.08.031.

CACICEDO, M.L., MANZO, R.M., MUNICOY, S., BONAZZA, H.L., ISLAN, G.A., DESIMONE, M., BELLINO, M., MAMMARELLA, E.J. and CASTRO, G.R. (2019). Immobilized enzymes and their applications. In: R.S. SINGH, R.R. SINGHANIA, A. PANDEY and C. LARROCHE, eds. Advances in enzyme technology. USA: Elsevier, pp. 169-200. http://dx.doi.org/10.1016/B978-0-44464114-4.00007-8.

CAI, C., GAO, Y., LIU, Y., ZHONG, N. and LIU, N., 2016. Immobilization of Candida antarctica lipase B onto SBA-15 and their application in glycerolysis for diacylglycerols synthesis. Food Chemistry, vol. 212, pp. 205-212. http://dx.doi.org/10.1016/j. foodchem.2016.05.167. PMid:27374525.

CHEN, Y., XU, Y. and XIAO-MEI, W., 2015. Efficient improving the activity and enantioselectivity of Candida rugosa lipase for the resolution of naproxen by enzyme immobilization on MCM-41 mesoporous molecular sieve. International Journal Bioautomation, vol. 19, no. 3, pp. 325.

CHOI, J.-M., HAN S.-S. and KIM, H.-S., 2015. Industrial applications of enzyme biocatalysis: current status and future aspects. 
Biotechnology Advances, vol. 33, no. 7, pp. 1443-1454. http:// dx.doi.org/10.1016/j.biotechadv.2015.02.014.

COSTA, J.A.S., DE JESUS, R.A., SANTOS, D.O., MANO, J.F., ROMÃO, L.P. and PARANHOS, C.M., 2020. Recent progresses in the adsorption of organic, inorganic, and gas compounds by MCM41-based mesoporous materials. Microporous and Mesoporous Materials, vol. 291, pp. 109698. http://dx.doi.org/10.1016/j. micromeso.2019.109698.

CUI, J., TAN, Z., HAN, P., ZHONG, C. and JIA, S., 2017. Enzyme shielding in a large mesoporous hollow silica shell for improved recycling and stability based on $\mathrm{CaCO} 3$ microtemplates and biomimetic silicification. Journal of Agricultural and Food Chemistry, vol. 65, no. 19, pp. 3883-3890. http://dx.doi.org/10.1021/acs. jafc.7b00672. PMid:28452473.

CUI, J., REN, S., LIN, T., FENG, Y. and JIA, S., 2018a. Shielding effects of $\mathrm{Fe}_{3}+$-tannic acid nanocoatings for immobilized enzyme on magnetic $\mathrm{Fe}_{3} \mathrm{O}_{4} @$ silica core shell nanosphere. Chemical Engineering Journal, vol. 343, pp. 629-637. http://dx.doi. org/10.1016/j.cej.2018.03.002.

CUI, J., SUN, B., LIN, T., FENG, Y. and JIA, S., 2018b. Enzyme shielding by mesoporous organosilica shell on $\mathrm{Fe}_{3} \mathrm{O}_{4} @$ silica yolk-shell nanospheres. International Journal of Biological Macromolecules, vol. 117, pp. 673-682. http://dx.doi.org/10.1016/j. ijbiomac.2018.05.227. PMid:29859841.

DATTA, S., CHRISTENA, L. R. and RAJARAM, Y. R. S., 2013. Enzyme immobilization: an overview on techniques and support materials. 3 Biotech, vol. 3, no. 1, pp. 1-9. http://dx.doi. org/10.1007/s13205-012-0071-7.

DWEVEDI, A. (2016). Enzyme Immobilization: advances in industry, agriculture, medicine, and the environment. USA: Springer. http:// dx.doi.org/10.1007/978-3-319-41418-8.

ENDER, F., WEISER, D., NAGY, B., BENCZE, C. L., PAIZS, C., PÁLOVICS, P. and POPPE, L., 2016. Microfluidic multiple cell chip reactor filled with enzyme-coated magnetic nanoparticles-an efficient and flexible novel tool for enzyme catalyzed biotransformations. Journal of Flow Chemistry, vol. 6, no. 1, pp. 43-52.

ESCAMILLA-ALVARADO, C., PÉREZ-PIMIENTA, J. A., PONCE-NOYOLA, T., and POGGI-VARALDO, H. M., 2017. An overview of the enzyme potential in bioenergy-producing biorefineries. vol. 92, no. 5 , pp. 906-924. https://doi.org/10.1002/jctb.5088.

ESCUIN, P. C., GARCÍA-BENNETT, A., ROS-LIS, J. V., FOIX, A. A., and ANDRÉS, A. J., 2017. Application of mesoporous silica materials for the immobilization of polyphenol oxidase. Food Chemistry, vol. 217, pp. 360-363. http://dx.doi.org/10.1016/j. foodchem.2016.08.02.

FEI, X., CHEN, S., LIU, D., HUANG, C. and ZHANG, Y., 2016. Comparison of amino and epoxy functionalized SBA-15 used for carbonic anhydrase immobilization. Journal of Bioscience and Bioengineering, vol. 122, no. 3, pp. 314-321. http://dx.doi. org/10.1016/j.jbiosc.2016.02.004. PMid:27215831.

FELLENZ, N., PEREZ-ALONSO, F.J., MARTIN, P.P., GARCÍA-FIERRO, J.L., BENGOA, J.F., MARCHETTI, S.G. and ROJAS, S., 2017. Chromium (VI) removal from water by means of adsorption-reduction at the surface of amino-functionalized MCM-41 sorbents. Microporous and Mesoporous Materials, vol. 239, pp. 138-146. http://dx.doi.org/10.1016/j.micromeso.2016.10.012.

FLETCHER, E.E., YAN, D., KOSIBA, A.A., ZHOU, Y. and SHI, H., 2019. Biotechnological applications of elastin-like polypeptides and the inverse transition cycle in the pharmaceutical industry. Protein Expression and Purification, vol. 153, pp. 114-120. http:// dx.doi.org/10.1016/j.pep.2018.09.006. PMid:30217600.

GAO, J., YU, H., ZHOU, L., HE, Y., MA, L. and JIANG, Y., 2017a. Formation of cross-linked nitrile hydratase aggregates in the pores of tannic-acid-templated magnetic mesoporous silica: characterization and catalytic application. Biochemical Engineering Journal, vol. 117, no. Pt A, pp. 92-101. http://dx.doi. org/10.1016/j.bej.2016.10.005.

GAO, J., ZHANG, Z., JIANG, Y., CHEN, Y. and GAO, S., 2017b. Biomimeticfunctionalized, tannic acid-templated mesoporous silica as a new support for immobilization of NHase. Molecules (Basel, Switzerland), vol. 22, no. 10, pp. 1597. http://dx.doi.org/10.3390/ molecules22101597. PMid:28946697.

GHOLAMZADEH, P., MOHAMMADI ZIARANI, G. and BADIEI, A., 2017. Immobilization of lipases onto the SBA-15 mesoporous silica. Biocatalysis and Biotransformation, vol. 35, no. 3, pp. 131-150. http://dx.doi.org/10.1080/10242422.2017.1308495.

GKANIATSOU, E., SICARD, C., RICOUX, R., BENAHMED, L., BOURDREUX, F., ZHANG, Q., SERRE, C., MAHY, J.P. and STEUNOU, N., 2018. Enzyme encapsulation in mesoporous metal-organic frameworks for selective biodegradation of harmful dye molecules. Angewandte Chemie, vol. 130, no. 49, pp. 16141-16146. http://dx.doi.org/10.1002/ange.201811327. PMid:30307095.

GUERRAND, D. (2017). Lipases industrial applications: focus on food and agroindustries. Paris: EDP Sciences.

GURUNG, N., RAY, S., BOSE S., and RAI, V., 2013. A broader view: microbial enzymes and their relevance in industries, medicine, and beyond. BioMed Research International, vol. 2013, pp. 32912.

HAN, W., LAM, W.C., MELIKOGLU, M., WONG, M.T., LEUNG, H.T., NG, C.L., YAN, P., YEUNG, S.Y. and LIN, C.S.K., 2015. Kinetic analysis of a crude enzyme extract produced via solid state fermentation of bakery waste. ACS Sustainable Chemistry \&' Engineering, vol. 3, no. 9, pp. 2043-2048. http://dx.doi. org/10.1021/acssuschemeng.5b00323.

JEGANNATHAN, K. R. and NIELSEN, P. H., 2013. Environmental assessment of enzyme use in industrial production-a literature review. Journal of Cleaner Production, vol. 42, pp. 228-240.

JIANG, B., DOU, B., WANG, K., SONG, Y., CHEN, H., ZHANG, C., XU, Y. and LI, M., 2016. Hydrogen production from chemical looping steam reforming of glycerol by Ni based Al-MCM-41 oxygen carriers in a fixed-bed reactor. Fuel, vol. 183, pp. 170-176. http:// dx.doi.org/10.1016/j.fuel.2016.06.061.

KLEIN, M.P., HACKENHAAR, C.R., LORENZONI, A.S., RODRIGUES, R.C., COSTA, T.M., NINOW, J.L. and HERTZ, P.F., 2016. Chitosan crosslinked with genipin as support matrix for application in food process: support characterization and $\beta$-d-galactosidase immobilization. Carbohydrate Polymers, vol. 137, pp. 184-190. http://dx.doi.org/10.1016/j.carbpol.2015.10.069. PMid:26686119.

KONG, L., ZHOU, X., YAO, Y., JIAN, P. and DIAO, G., 2016. Catalytic wet peroxide oxidation of aniline in wastewater using copper modified SBA-15 as catalyst. Environmental Technology, vol. 37, no. 3, pp. 422-429. http://dx.doi.org/10.1080/09593330.2015. 1071434. PMid:26227827.

KUMARI, A., KAUR, B., SRIVASTAVA, R. and SANGWAN, R.S., 2015. Isolation and immobilization of alkaline protease on mesoporous silica and mesoporous ZSM-5 zeolite materials for improved catalytic properties. Biochemistry and Biophysics Reports, vol. 2, pp. 108-114. http://dx.doi.org/10.1016/j.bbrep.2015.05.009. PMid:29124151.

LANDARANI-ISFAHANI, A., TAHERI-KAFRANI, A., AMINI, M., MIRKHANI, V., MOGHADAM, M., SOOZANIPOUR, A. and RAZMJOU, A., 2015. Xylanase immobilized on novel multifunctional hyperbranched polyglycerol-grafted magnetic nanoparticles: an efficient and robust biocatalyst. Langmuir, vol. 31, no. 33, pp. 9219-9227. http://dx.doi.org/10.1021/acs. langmuir.5b02004. PMid:26258956. 
LI, K., WANG, J., HE, Y., CUI, G., ABDULRAZAQ M.A. and YAN, Y., 2018. Enhancing enzyme activity and enantioselectivity of Burkholderia cepacia lipase via immobilization on melamineglutaraldehyde dendrimer modified magnetic nanoparticles. Chemical Engineering Journal, vol. 351, pp. 258-268. http:// dx.doi.org/10.1016/j.cej.2018.06.086.

LIU, J., XIAO, J., LI, F., SHI, Y., LI, D. and HUANG, Q., 2018. Chitosansodium alginate nanoparticle as a delivery system for $\varepsilon$-polylysine: Preparation, characterization and antimicrobial activity. Food Control, vol. 91, pp. 302-310. http://dx.doi. org/10.1016/j.foodcont.2018.04.020.

LYNCH, M.M., LIU, J., NIGRA, M. and COPPENS, M.-O., 2016. Chaperonin-inspired $\mathrm{pH}$ protection by mesoporous silica SBA15 on myoglobin and lysozyme. Langmuir, vol. 32, no. 37, pp. 9604-9610. http://dx.doi.org/10.1021/acs.langmuir.6b02832. PMid:27564659.

MA, H.-F., MENG, G., CUI, B.-K., SI, J. and DAI, Y.-C., 2018. Chitosan crosslinked with genipin as supporting matrix for biodegradation of synthetic dyes: laccase immobilization and characterization. Chemical Engineering Research \& Design, vol. 132, pp. 664-676. http://dx.doi.org/10.1016/j.cherd.2018.02.008.

MAHTO, T.K., CHOWDHURI, A.R., SAHOO, B. and SAHU, S.K., 2016. Polyaniline-functionalized magnetic mesoporous nanocomposite: A smart material for the immobilization of lipase. Polymer Composites, vol. 37, no. 4, pp. 1152-1160. http:// dx.doi.org/10.1002/pc.23278.

MAJEWSKI, M.B., HOWARTH, A.J., LI, P., WASIELEWSKI, M.R., HUPP, J.T. and FARHA, O.K., 2017. Enzyme encapsulation in metal-organic frameworks for applications in catalysis. CrystEngComm, vol. 19, no. 29, pp. 4082-4091. http://dx.doi.org/10.1039/C7CE00022G.

MELÉNDEZ-ORTIZ, H.I., PUENTE-URBINA, B., CASTRUITA-DE LEON, G., MATA-PADILLA, J.M. and GARCÍA-URIOSTEGUI, L., 2016. Synthesis of spherical SBA-15 mesoporous silica. Influence of reaction conditions on the structural order and stability. Ceramics International, vol. 42, no. 6, pp. 7564-7570. http:// dx.doi.org/10.1016/j.ceramint.2016.01.163.

MINTEER, S.D. (2017). Enzyme stabilization and immobilization. USA: Springer. http://dx.doi.org/10.1007/978-1-4939-6499-4.

MOHAMAD, N. R., MARZUKI, N. H. C., BUANG, N. A., HUYOP, F., and WAHAB, R. A., 2015. An overview of technologies for immobilization of enzymes and surface analysis techniques for immobilized enzymes. Biotechnology \& Biotechnological Equipment, vol. 29, no. 2, pp. 205-220.

MOJSOV, K. Aspergillus enzymes for food industries. In: V.K. GUPTA, ed. New and Future Developments in Microbial Biotechnology and Bioengineering. USA: Elsevier, 2016, pp. 215-222. http://dx.doi. org/10.1016/B978-0-444-63505-1.00033-6.

MOLAEI, S., TAMORADI, T., GHADERMAZI, M. and GHORBANICHOGHAMARANI, A., 2018. Synthesis and characterization of MCM-41@AMPD@Zn as a novel and recoverable mesostructured catalyst for oxidation of sulfur containing compounds and synthesis of 5-substituted tetrazoles. Microporous and Mesoporous Materials, vol. 272, pp. 241-250. http://dx.doi. org/10.1016/j.micromeso.2018.06.048.

NGUYEN, H.H. and KIM, M., 2017. An overview of techniques in enzyme immobilization. Applied Science and Convergence Technology, vol. 26, no. 6, pp. 157-163. http://dx.doi.org/10.5757/ ASCT.2017.26.6.157.

PATEL, A.K., SINGHANIA, R.R. and PANDEY, A., 2016. Novel enzymatic processes applied to the food industry. Current Opinion in Food Science, vol. 7, pp. 64-72. http://dx.doi.org/10.1016/j. cofs.2015.12.002.
POLIKARPOVA, P., AKOPYAN, A., SHIGAPOVA, A., GLOTOV, A., ANISIMOV, A. and KARAKHANOV, E., 2018. Oxidative desulfurization of fuels using heterogeneous catalysts based on MCM-41. Energy \& Fuels, vol. 32, no. 10, pp. 10898-10903. http://dx.doi.org/10.1021/acs.energyfuels.8b02583.

POORAKBAR, E., SHAFIEE, A., SABOURY, A.A., RAD, B.L., KHOSHNEVISAN, K., MA'MANI, L., DERAKHSHANKHAH, H., GANJALI, M.R. and HOSSEINI, M., 2018. Synthesis of magnetic gold mesoporous silica nanoparticles core shell for cellulase enzyme immobilization: improvement of enzymatic activity and thermal stability. Process Biochemistry, vol. 71, pp. 92-100. http://dx.doi.org/10.1016/j.procbio.2018.05.012.

RIOS, N.S., PINHEIRO, M.P., DOS SANTOS, J.C.S., FONSECA, T.S., LIMA, L.D., DE MATTOS, M.C., FREIRE, D.M., DA SILVA JÚNIOR, I.J., RODRÍGUEZ-AGUADO, E. and GONCALVES, L.R., 2016. Strategies of covalent immobilization of a recombinant Candida antarctica lipase B on pore-expanded SBA-15 and its application in the kinetic resolution of (R, S)-Phenylethyl acetate. Journal of Molecular Catalysis. B, Enzymatic, vol. 133, pp. 246-258. http:// dx.doi.org/10.1016/j.molcatb.2016.08.009.

RIOS, N.S., PINHEIRO, M.P., LIMA, M.L.B., FREIRE, D.M.G., DA SILVA JÚNIOR, I.J., RODRÍGUEZ-CASTELLÓN, E., DE SANT'ANA, H.B., MACEDO, A.C. and GONÇALVES, L.R.B., 2018. Pore-expanded SBA-15 for the immobilization of a recombinant Candida antarctica lipase B: application in esterification and hydrolysis as model reactions. Chemical Engineering Research \& Design, vol. 129, pp. 12-24. http://dx.doi.org/10.1016/j.cherd.2017.10.032.

RUEDA, N., DOS SANTOS, J.C., ORTIZ, C., TORRES, R., BARBOSA, O., RODRIGUES, R.C., BERENGUER-MURCIA, Á. and FERNANDEZLAFUENTE, R., 2016. Chemical modification in the design of immobilized enzyme biocatalysts: drawbacks and opportunities. Chemical Record (New York, N.Y.), vol. 16, no. 3, pp. 1436-1455. http://dx.doi.org/10.1002/tcr.201600007. PMid:27166751.

RUI, Y., WU, X., MA, B. and XU, Y., 2018. Immobilization of acetylcholinesterase on functionalized SBA-15 mesoporous molecular sieve for detection of organophosphorus and carbamate pesticide. Chinese Chemical Letters, vol. 29, no. 9, pp. 1387-1390.

SADIGHI, A., MOTEVALIZADEH, S.F., HOSSEINI, M., RAMAZANI, A., GORGANNEZHAD, L., NADRI, H., DEIHAM, B., GANJALI, M.R., SHAFIEE, A., FARAMARZI, M.A. and KHOOBI, M., 2017. Metalchelate immobilization of lipase onto polyethylenimine coated MCM-41 for apple flavor synthesis. Applied Biochemistry and Biotechnology, vol. 182, no. 4, pp. 1371-1389. http://dx.doi. org/10.1007/s12010-017-2404-9. PMid:28194717.

SANG, Y., LI, H., ZHU, M., MA, K., JIAO, Q. and WU, Q., 2013. Catalytic performance of metal ion doped MCM-41 for methanol dehydration to dimethyl ether. Journal of Porous Materials, vol. 20, no. 6, pp. 1509-1518. http://dx.doi.org/10.1007/s10934013-9737-8.

SANTOS, J.C.S., BARBOSA, O., ORTIZ, C., BERENGUER-MURCIA, A., RODRIGUES, R.C. and FERNANDEZ-LAFUENTE, R., 2015. Importance of the support properties for immobilization or purification of enzymes. ChemCatChem, vol. 7, no. 16, pp. 24132432. http://dx.doi.org/10.1002/cctc.201500310.

SHAHRESTANI, H., TAHERI-KAFRANI, A., SOOZANIPOUR, A. and TAVAKOLI, O., 2016. Enzymatic clarification of fruit juices using xylanase immobilized on 1,3,5-triazine-functionalized silicaencapsulated magnetic nanoparticles. Biochemical Engineering Journal, vol. 109, pp. 51-58. http://dx.doi.org/10.1016/j. bej.2015.12.013.

SHIRI, L., NARIMANI, H. and KAZEMI, M., 2018. Synthesis and characterization of sulfamic acid supported on $\mathrm{Fe}_{3} \mathrm{O}_{4}$ nanoparticles: a green, versatile and magnetically separable 
acidic catalyst for oxidation reactions and Knoevenagel condensation. Applied Organometallic Chemistry, vol. 32, no. 1, pp. e3927. http://dx.doi.org/10.1002/aoc.3927.

SHOKOUHIMEHR, M. J. C., 2015. Magnetically separable and sustainable nanostructured catalysts for heterogeneous reduction of nitroaromatics. Catalysts, vol. 5, no. 2, pp. 534-560.

SINGH, R.K., TIWARI, M.K., SINGH, R. and LEE, J.-K., 2013. From protein engineering to immobilization: promising strategies for the upgrade of industrial enzymes. International Journal of Molecular Sciences, vol. 14, no. 1, pp. 1232-1277. http://dx.doi. org/10.3390/ijms14011232. PMid:23306150.

SINGH, R.S., SINGHANIA, R.R., PANDEY, A. and LARROCHE, C. (2019). Biomass, biofuels, biochemicals: advances in enzyme technology. USA: Elsevier.

SUN, M.-H., HUANG, S.-Z., CHEN, L.-H., LI, Y., YANG, X.-Y., YUAN, Z.Y. and SU, B.-L., 2016. Applications of hierarchically structured porous materials from energy storage and conversion, catalysis, photocatalysis, adsorption, separation, and sensing to biomedicine. Chemical Society Reviews, vol. 45, no. 12, pp. 34793563. http://dx.doi.org/10.1039/C6CS00135A. PMid:27255561.

SUO, H., XU, L., XUE, Y., QIU, X., HUANG, H. and HU, Y., 2020. Ionic liquids-modified cellulose coated magnetic nanoparticles for enzyme immobilization: improvement of catalytic performance. Carbohydrate Polymers, vol. 234, pp. 115914. http://dx.doi. org/10.1016/j.carbpol.2020.115914. PMid:32070532.

VAGHARI, H., JAFARIZADEH-MALMIRI, H., MOHAMMADLOU, M. BERENJIAN, A., ANARJAN, N., JAFARI, N. and NASIRI, S., 2016. Application of magnetic nanoparticles in smart enzyme immobilization. Biotechnology Letters, vol. 38, no. 2, pp. 223-233. http://dx.doi.org/10.1007/s10529-015-1977-z. PMid:26472272.

WANG, M., QI, W., SU, R. and HE, Z., 2015. Advances in carrierbound and carrier-free immobilized nanobiocatalysts. Chemical Engineering Science, vol. 135, pp. 21-32. http://dx.doi. org/10.1016/j.ces.2015.03.051.

WONGVITVITCHOT, W., SIAMNIKORN, K., PITHAKRATANAYOTHIN, S., CHAISUWAN, T. and WONGKASEMJIT, S., 2019. Effective and reusable T. reesei immobilized on SBA- 15 for monomeric sugar production from cellulose hydrolysis. Bioresource Technology Reports, vol. 5, pp. 199-205. http://dx.doi.org/10.1016/j. biteb.2019.01.014.

WU, J.C.Y., HUTCHINGS, C.H., LINDSAY, M.J., WERNER, C.J. and BUNDY, B.C., 2015. Enhanced enzyme stability through sitedirected covalent immobilization. Journal of Biotechnology, vol. 193, pp. 83-90. http://dx.doi.org/10.1016/j.jbiotec.2014.10.039. PMid:25449015.

WU, N., LI, B., LIU, J., ZUO, S. and ZHAO, Y., 2016. Preparation and catalytic performance of a novel highly dispersed bifunctional catalyst Pt@ Fe-MCM-41. RSC Advances, vol.6, no. 16, pp. 1346113468. http://dx.doi.org/10.1039/C5RA21562E.

XIANG, X., DING, S., SUO, H., XU, C., GAO, Z. and HU, Y., 2018. Fabrication of chitosan-mesoporous silica SBA-15 nanocomposites via functional ionic liquid as the bridging agent for PPL immobilization. Carbohydrate Polymers, vol. 182, pp. 245-253. http://dx.doi.org/10.1016/j.carbpol.2017.11.031. PMid:29279121.

XIE, W. and ZANG, X., 2016. Immobilized lipase on core-shell structured $\mathrm{Fe}_{3} \mathrm{O}_{4}-\mathrm{MCM}-41$ nanocomposites as a magnetically recyclable biocatalyst for interesterification of soybean oil and lard. Food Chemistry, vol. 194, pp. 1283-1292. http://dx.doi. org/10.1016/j.foodchem.2015.09.009. PMid:26471683.

XU, X., MEGARAJAN, S.K., ZHANG, Y. and JIANG, H., 2019. Ordered mesoporous alumina and their composites based on evaporation induced self-assembly for adsorption and catalysis. Chemistry of Materials, vol. 32, no. 1, pp. 3-26.

YANG, X., QIU, P., YANG, J., FAN, Y., WANG, L., JIANG, W., CHENG, X., DENG, Y. and LUO, W., 2019. Mesoporous materials-based electrochemical biosensors from enzymatic to nonenzymatic. Small, vol. 17, no. 9, pp. 1904022. http://dx.doi.org/10.1002/ smll.201904022. PMid:31643131.

YANG, Y., WANG, S., ZHOU, Z., ZHANG, R., SHEN, H., SONG, J., SU, P. and YANG, Y., 2018. Enhanced reusability and activity: DNA directed immobilization of enzyme on polydopamine modified magnetic nanoparticles. Biochemical Engineering Journal, vol. 137, pp. 108-115. http://dx.doi.org/10.1016/j.bej.2018.05.019.

YUAN, J., XIONG, J., WANG, J., DING, W., YANG, L., ZHANG, M., ZHU, W. and LI, H., 2016. Structure and catalytic oxidative desulfurization properties of SBA-15 supported silicotungstic acid ionic liquid. Journal of Porous Materials, vol. 23, no. 3, pp. 823-831. http://dx.doi.org/10.1007/s10934-016-0137-8.

ZDARTA, J., MEYER, A. S., JESIONOWSKI, T. and PINELO, M., 2018. A general overview of support materials for enzyme immobilization: characteristics, properties, practical utility. Catalysts, vol. 8, no. 2, pp. 92.

ZHANG, S., WANG, K., HUANG, C., LI, Z., SUN, T. and HAN, D.-M., 2016. An enzyme-free and resettable platform for the construction of advanced molecular logic devices based on magnetic beads and DNA. Nanoscale, vol. 8, no. 34, pp. 15681-15688. http:// dx.doi.org/10.1039/C6NR04762A. PMid:27524500.

ZHAO, X., QI, F., YUAN, C., DU, W. and LIU, D., 2015. Lipase-catalyzed process for biodiesel production: enzyme immobilization, process simulation and optimization. Renewable and Sustainable Energy Reviews, vol. 44, pp. 182-197.

ZHAO, Z., ZHOU, M.-C. and LIU, R.--L., 2019. Recent Developments in Carriers and Non-Aqueous Solvents for Enzyme Immobilization. Catalysts, vol. 9, no. 8, pp. 647.

ZHONG, N., LI, Y., CAI, C., GAO, Y., LIU, N., LIU, G., TAN, W. and ZENG, Y., 2018. Enhancing the catalytic performance of Candida antarctica lipase B by immobilization onto the ionic liquids modified SBA-15. European Journal of Lipid Science and Technology, vol. 120, no. 4, pp. 1700357. http://dx.doi.org/10.1002/ejlt.201700357.

ZHONG, N., CHEN, W., LIU, L. and CHEN, H., 2019. Immobilization of Rhizomucor miehei lipase onto the organic functionalized SBA-15: their enzymatic properties and glycerolysis efficiencies for diacylglycerols production. Food Chemistry, vol. 271, pp. 739-746. http://dx.doi.org/10.1016/j.foodchem.2018.07.185. PMid:30236739.

ŽIVKOVIĆ, L.T.I., ŽIVKOVIĆ, L.S., BABIĆ, B.M., KOKUNEŠOSKI, M.J., JOKIĆ, B.M. and KARADŽIĆ, I.M., 2015. Immobilization of Candida rugosa lipase by adsorption onto biosafe meso/macroporous silica and zirconia. Biochemical Engineering Journal, vol. 93, pp. 73-83. http://dx.doi.org/10.1016/j.bej.2014.09.012.

ZOU, B., HU, Y., JIANG, L., JIA, R., and HUANG, H., 2013. Mesoporous material SBA-15 modified by amino acid ionic liquid to immobilize lipase via ionic bonding and cross-linking method. Industrial \& Engineering Chemistry Research, vol. 52, no. 8, pp. 2844-2851. 